\title{
Pengembangan Aplikasi Sistem Informasi Smart Register Online Berbasis Android Menggunakan Algoritma BruteForce
}

\author{
Dimas Dandy Aryarajendra Suprapto ${ }^{1}$, Fauziah ${ }^{2}$, Iskandar Fitri ${ }^{3}$, Nur Hayati ${ }^{4}$ \\ ${ }_{1,2,3,4}$ Program Studi Informatika, Universitas Nasional \\ email: dimazdandy@gmail.com ${ }^{1}$, fauziah@civitas.unas.ac.id ${ }^{2}$, \\ iskandarfitri@civitas.unas.ac.id ${ }^{3}$, nurhayati@civitas.unas.ac.id ${ }^{4}$
}

(Received: 8 April 2020/ Accepted: 26 April 2020 / Published Online: 20 Juni 2020)

\begin{abstract}
Abstrak
Pada proses pendaftaran mahasiswa baru (PMB) untuk berbagai informasi ditampilkan pada sistem informasi pmb berbasis website. Tetapi kendala dalam penggunaan website adalah calon mahasiswa baru harus sering memantau website untuk memperoleh informasi, bila tidak maka camaba beresiko tertinggal informasi terbaru. Penelitian ini bertujuan untuk mengembangkan sistem informasi registrasi online pada pendaftaran mahasiswa baru yang sebelumnya berbasis website dan dikembangkan menjadi aplikasi berbasis Android. Sehingga sangat memudahkan camaba dalam mengakses informasi pmb dan pendaftaran melalui aplikasi Android. Penelitian ini merancang aplikasi sistem informasi pendaftaran berbasis Android menggunakan metode waterfall, algortima bruteforce, terintegrasi dengan database firebase realtime dan cloud firebase storage. Hasil pengujian algoritma brute force pada pencarian kata "Teknik Informatika S1" dengan input string "Informatika" dilakukan 8 langkah pencarian. Pada pengujian whitebox dengan menghitung parameter cyclomatic complexity, region, dan independent path dari 4 pengujian whitebox diperoleh hasil sama yaitu berjumlah 16. Pada hasil pengujian aplikasi dengan metode blackbox dinyatakan berhasil dan hasil pengujian sesuai yang diharapkan. Jadi dapat disimpulkan pengembangan aplikasi sistem informasi smart register online menggunakan algoritma brute force dikatakan layak digunakan dalam proses pendaftaran mahasiswa baru sesuai dengan pengujian yang telah dilakukan.
\end{abstract}

Kata kunci: Android, Aplikasi, BruteForce, PMB, Sistem Informasi

\begin{abstract}
The process of registering new students (PMB) for sharing information displayed on the website based PMB information system. However, constraints in the usage of the website are prospective students must monitor the website frequently to obtain information. If not accordingly a student is at risk of lagging behind the latest information. The research aims to expand a registration information system on the enrollment of student-based websites and developed into an Android-based application. So it is very easy for students to access PMB information, and registration through the Android application. This study designed an Android-based registration information system application using the waterfall method, brute force algorithm, integrated realtime firebase database and firebase storage cloud. The results of testing the brute force algorithm on the word search "S1 Informatics Engineering" with the input string "Informatics" carried out 8 steps of searching. These results by calculating the parameters of cyclomate complexity, region, and independent path from whitebox tests obtained the same results, the amount of 16. The results of testing blackbox method declared successful and as expected. So it can be concluded the development of an online smart register information apply the brute force algorithm is said to be feasible to implementation in the process of registering new students in accordance with the testing that has been done.
\end{abstract}

Keywords: Android, Applications, BruteForce, PMB, Information System 


\section{PENDAHULUAN}

Penerimaan Mahasiswa Baru (PMB) adalah kegiatan yang rutin dilaksanakan oleh Perguruan Tinggi tiap ajaran baru untuk memperoleh mahasiswa baru. Pada proses PMB, berbagai informasi ditampilkan pada sistem informasi PMB. Sistem informasi merupakan sistem yang disusun secara sistematik dan teratur dari jaringan-jaringan aliran informasi yang menghubungkan setiap bagian dari suatu sistem, sehingga memungkinkan diadakannya komunikasi antar bagian atau satuan fungsional (Irawan, Hasna, \& Pahlevi, 2016).

Sistem informasi pendaftaran mahasiswa baru atau smart register online adalah suatu sistem informasi yang berisi pemberitahuan seputar pmb baik prosedur pendaftaran, biaya kuliah, ujian yang dilakukan, informasi prodi, dan melakukan pendaftaran secara online. Biasanya sistem informasi penerimaan mahasiswa baru berupa website. Akan tetapi kendala dalam penggunaan website adalah calon mahasiswa baru harus sering memantau website untuk memperoleh informasi, bila camaba tidak sering memantau website PMB maka mereka beresiko ketinggalan informasi yang up to date. Oleh karena itu, untuk menyelesaikan permasalahan diatas dibutuhkan suatu aplikasi sistem informasi PMB berbasis Android dengan bahasa pemrograman Java dan dibuat menggunakan platform Android Studio.

Android adalah sistem operasi mobile yang berkembang saat ini dan berbasi linux kernel yang dirancang untuk perangkat seluler layar sentuh dan komputer tablet. Android yang disebarkan secara open source dan menggunakan bahasa pemograman java (Sitanggang, Loi, \& Indra, 2019). Java adalah bahasa pemrograman berorientasi objek dengan elemen arsitektur mendasar dalam suatu program yaitu class yang secara kolektif mendefinisikan semua fitur dan fungsi aplikasi (Klausen, 2017). Android Studio adalah lingkungan terpadu Integrated Development Environment (IDE) untuk mengembangkan aplikasi android berdasarkan IntelliJ IDEA yang dibuat oleh Google (Utomo, Budiman, \& Triono, 2017).

Selain perkembangan teknologi aplikasi Android yang semakin pesat, aplikasi sistem berbasis Android memudahkan camaba dalam mengakses informasi seputar pmb dan melakukan pendaftaran secara online dengan lebih efektif dan efisien. Kelebihan sistem informasi pmb berbasis Android dibanding website adalah camaba tidak perlu mengetikkan alamat dan membuka situs pmb untuk mendapatkan informasi, camaba hanya perlu membuka aplikasi sistem informasi pmb berbasis Android karena lebih efektif dan efeisien.

Sejumlah peneliti telah mengembangkan sistem informasi diberbagai bidang menggunakan tool, IDE, dan database yang berbeda beda diantaranya (Amin, Maseleno, Shankar, Perumal, Vidhyavathi, \& Lakshmanaprabu, 2018; Choi \& Park, 2017; Khoiriyah \& Manikam, 2019; Kim, Bae, \& Choi, 2018; Kouziokas, 2016; Yulistina \& Arianti, 2019).

Sementara itu penelitian yang telah dilakukan Pramana, Watrianthos, \& Purnama (2019) telah membuat aplikasi sistem informasi pendaftaran mahasiswa baru AMIK Labuhan Batu berbasis android namun baru menerapkan mengenai form pendaftaran yang menggunakan database mysql Kemudian pada hasil penelitian yang dilakukan Yuni (2019) aplikasi penerimaan mahasiswa baru berbasis android menerapakan sistem informasi pendaftaran yang sudah terhubungan dengan database firebase dan menyediakan informasi pmb tetapi belum menggunakan algoritma dalam proses pendaftaran.

Berdasarkan pada penelitian sebelumnya, peneliti mengembangkan aplikasi sistem informasi pendaftaran mahasiswa baru secara online berbasis Android yang berisikan seluruh informasi PMB mulai dari prosedur pendaftaran, biaya kuliah, lokasi ujian, materi ujian, jenjang akademik (prodi), kelas karyawan, beasiswa, dll. Kemudian melakukan pendaftaran secara online melalui aplikasi yang telah terintegrasi dengan database firebase realtime, cloud firebase storage dan menggunakan metode waterfall dalam perancagan aplikasi serta implementasi algoritma brute force dalam proses pendaftaran. Dengan adanya aplikasi sistem informasi PMB berbasis Android, calon mahasiswa baru dapat dipermudah dalam 
mendapatkan informasi sehingga tidak ketinggalan informasi penting dan dapat melakukan pendaftaran secara online melalui aplikasi Android.

\section{METODE}

Penelitian ini menggunakan metode waterfall dengan pendekatan sistematis dan berurutan dalam pengembangan aplikasi dan algoritma brute force dalam pencarian string program studi saat melakukan pendaftaran. Metode waterfall adalah metode yang dilakukan dalam perancangan suatu sistem dengan secara sistematis dan berutan. Menurut Pressman (2015:42), metode waterfall adalah metode klasik yang bersifat sistematis, berurutan dalam membangun software. Berikut adalah tahapan dalam metode waterfall:

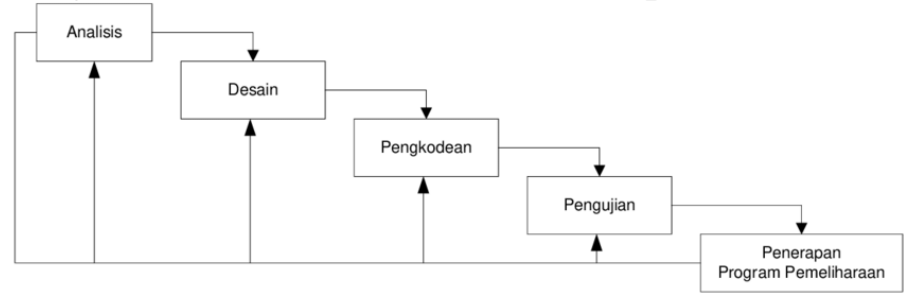

Gambar 1. Metode Waterfall

Langkah awal yaitu analisis terhadap kebutuhan sistem dengan cara pengumpulan data melalui penelitian, observasi, dan studi literatur. Langkah kedua yakni merancang desain tampilan dari aplikasi yang akan dibuat dan membuat use case diagram.

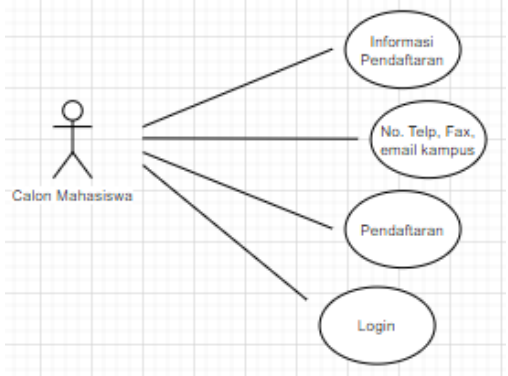

Gambar 2. Use case diagram Rancangan Sistem

Pada gambar 2 merupakan use case diagram yaitu penjelasan interaksi antara user dengan sistem yang ada yang dipresentasikan dengan langkah sederhana. Langkah ketiga yakni penulisan kode program dengan menggunakan Android Studio bahasa pemrograman java. Langkah keempat adalah pengujian program menggunakan metode whitebox dan blackbox untuk mendapatkan hasil keberhasilan dalam pengujian aplikasi. Langkah kelima yakni tahap pemeliharaan dilakukan perbaikan pada sistem aplikasi. Algoritma Brute Force adalah algoritma pendekatan secara langsung, sederhana, dan jelas yang digunakan dalam mencocokan string dengan membandingkan tiap karakter demi karakter. Berikut adalah langkah-langkah algoritma brute force untuk mencocokan string (Sumi, Purnawansyah, \& Syafie, 2018). Pencocokan string dimulai pada awal teks, membandingkan karakter demi karakter dari kiri ke kanan, dan jika pada langkah 1 string belum menemukan kecocokan pada teks akan terus bergeser ke kanan dan berulang ke langkah 2 hingga langkah selanjutnya dan menemukan kecocokan antara teks dan string.

\section{HASIL DAN PEMBAHASAN}

\section{Hasil Penelitian}

Aplikasi yang dikembangkan dalam penelitian ini adalah aplikasi smart register online berbasis Android menggunakan algoritma brute force. Pengembangan aplikasi dilakukan dengan menggunakan metode pendekatan Waterfall dengan langkah-langkah 
pelaksanaan penelitian dan pengembangan sebanyak 5 tahapan, yaitu: Analisis sistem, Desain sistem, Coding, Testing, Pemeliharaan. Hasil pengembangan aplikasi smart register online berbasis Android dapat dilihat pada gambar 3 dan 4.

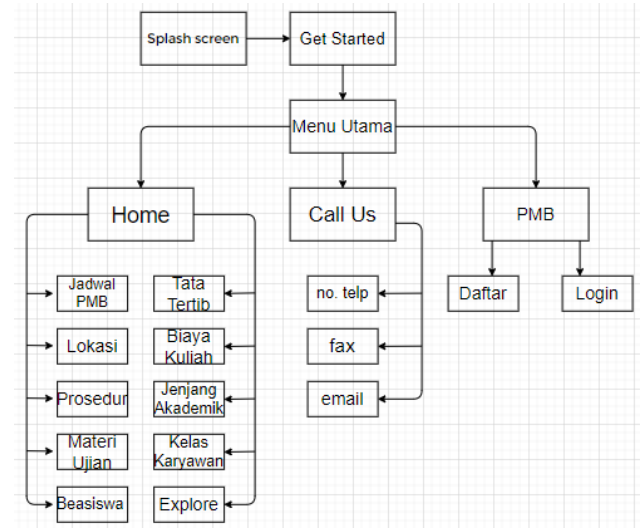

Gambar 3. User Flow

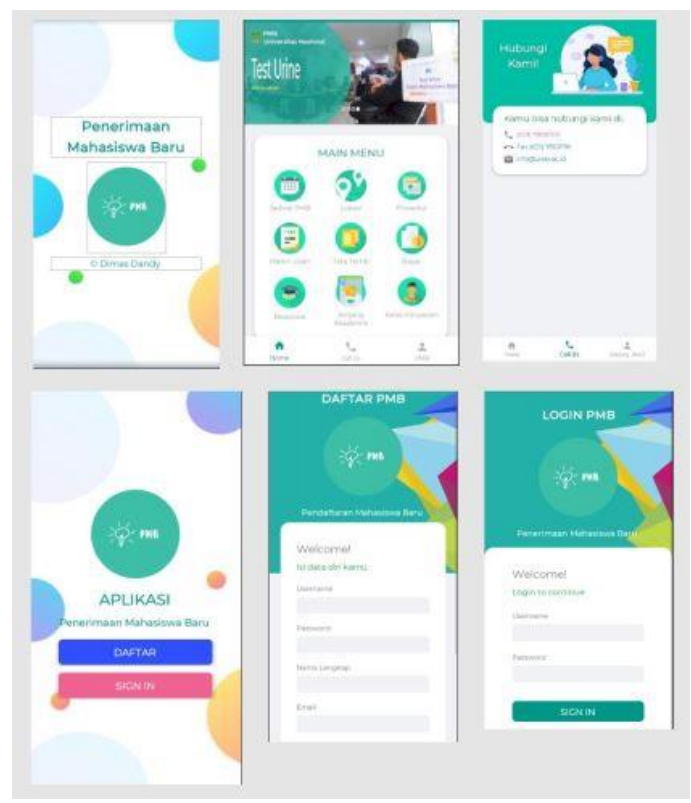

Gambar 4. Tampilan Aplikasi

Pada gambar 3 adalah user flow yaitu langkah yang dilakukan user untuk mencari informasi dan pendaftaran pada aplikasi sistem informasi registrasi online. Sementara itu Pada gambar 4 adalah tampilan desain aplikasi yang terdiri dari splash screen, main menu Home, menu navigasi Call us, menu navigasi PMB, halaman daftar dan login. Splash screen adalah halaman ketika membuka aplikasi pertama kali, kemudian masuk main menu Home. Pada Home terdapat menu jadwal PMB, lokasi, prosedur, materi ujian, biaya, beasiswa, jenjang akademik dan kelas karyawan. Kemudian pada menu navigasi Call us terdapat kontak PMB berupa nomor telepon, email, dan fax. Pada menu navigasi PMB calon mahasiswa baru dapat melakukan pendaftaran secara online melalui aplikasi dan login setelah daftar.

\section{Hasil Uji Implementasi Algoritma Brute Force}

Penerapan algoritma brute force adalah ketika mengisi form program studi. Algoritma ini dibutuhkan dalam pencarian nama-nama program studi sehingga camaba tidak perlu mengetikkan seluruh teks program studi yang dicari. Pada form ini juga diberikan option selection menggunakan dropdown. 


\section{Program Studi \\ informatikal \\ Teknik Informatika S1}

Gambar 5. Form Pengisian Program Studi

Pada gambar 5 merupakan form pengisian program studi. Disini user akan mencari jurusan teks "Teknik Informatika S1" dengan string" informatika". Berikut adalah penerapan algoritma brute force pada kasus diatas.

1. Penelusuran Langkah 1

Tabel 1. Langkah 1

\begin{tabular}{llllllllllllllllllllll}
\hline \multicolumn{11}{c}{ Langkah 1 } & 111 \\
\hline Prodi & T & e & k & n & I & k & & I & n & f & o & r & m & a & t & i & k & a & & S & 1 \\
String & I & n & f & o & R & m & a & t & i & k & a & & & & & & & & & \\
\hline
\end{tabular}

Pada tabel 1 bandingkan huruf pertama string input dengan string pertama prodi, terjadi proses pencocokan string atau huruf yang sama. Bila belum terjadi kecocokan antra string prodi dan string input, maka proses pencocokan akan terus berlangsung.

2. Penelusuran Langkah 2

Tabel 2. Langkah 2

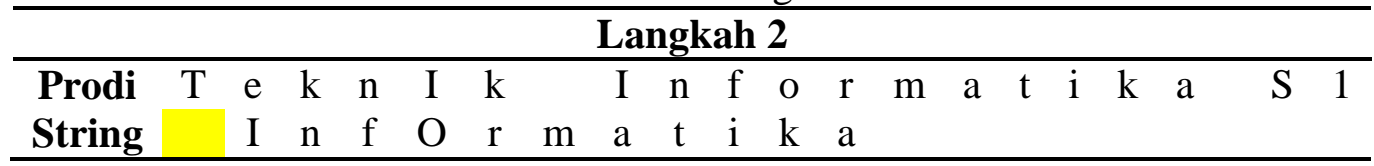

Pada tabel 2 masih sama seperti tabel 1, belum bertemu string yang cocok sehingga proses masih berlanjut.

3. Penelusuran Langkah 3

Tabel 3. Langkah 3

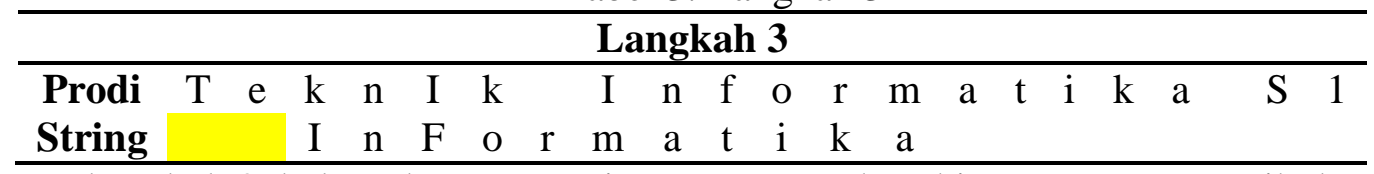

Pada tabel 3 belum bertemu string yang cocok sehingga proses masih berlanjut. Hingga string prodi dan string input cocok.

4. Penelusuran Langkah 4

Tabel 4. Langkah 4

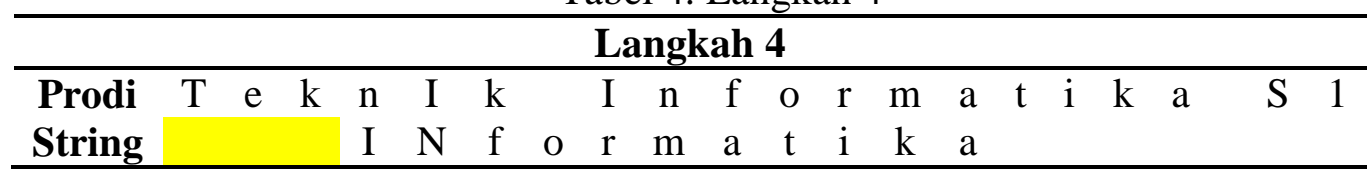

Pada tabel 4 string belum cocok, tetap melakukan pergeseran ke kanan.

5. Penelusuran Langkah 5

Tabel 5. Langkah 5

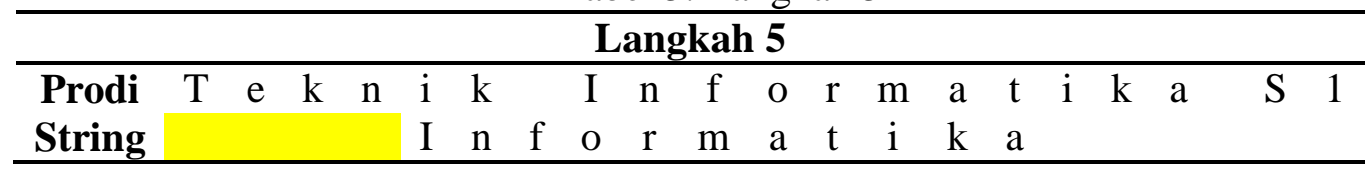

Pada tabel 5 string belum cocok, tetap melakukan pergeseran ke kanan.

6. Penelusuran Langkah 6

Tabel 6. Langkah 6

\begin{tabular}{llllllllllllllllllllll}
\hline \multicolumn{11}{c}{ Langkah 6 } & 111 \\
\hline Prodi & T & e & k & n & i & k & & I & n & f & o & r & m & a & t & i & k & a & & S & 1 \\
String & & & & & & I & n & f & o & r & m & a & t & i & k & a & & & & \\
\hline
\end{tabular}

Pada tabel 6 string belum cocok, tetap melakukan pergeseran ke kanan. 
7. Penelusuran Langkah 7

Tabel 7. Langkah 7

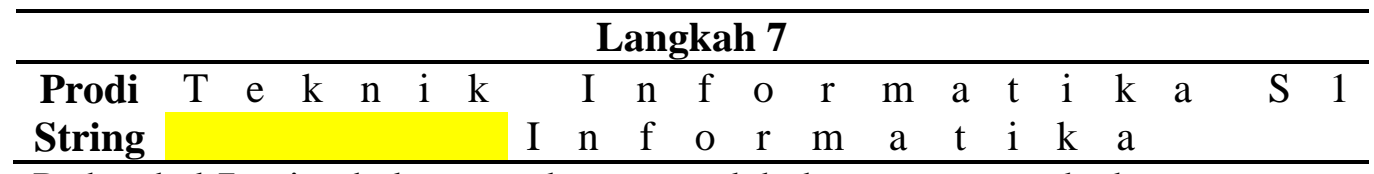

Pada tabel 7 string belum cocok, tetap melakukan pergeseran ke kanan.

8. Penelusuran Langkah 8

Tabel 8. Langkah 8

\begin{tabular}{ccccccccccccccccccccc}
\hline \multicolumn{11}{c}{ Langkah 8 } \\
\hline Prodi & T & e & k & n & I & k & I & n & f & o & r & m & a & t & i & k & a & & S & 1 \\
String & & & & & & & & I & n & f & o & r & m & a & t & i & k & a & & \\
\hline
\end{tabular}

Pada tabel 8 ditemukan bahwa string input sama dengan string prodi. Maka tidak lagi dilakukan pergeseran atau pencarian string kembali. Setelah melakukan pengujian hasil implementasi algoritma brute force, selanjut nya adalah pengujian aplikasi menggunakan metode whitebox dan blackbox.

\section{Hasil Pengujian Metode Whitebox pada Aplikasi}

Metode whitebox adalah pengujian software yang paling terstruktur dengan melihat kode dan struktur data. Pada pengujian aplikasi menggunakan whitebox terlebih dahulu membuat flowchart dan flowgraph. Flowchart digunakan pada tahapan perancangan untuk menggambarkan logika dari program sedangkan flowgraph digunakan pada tahapan pengujian yang berfokus pada penggambaran aliran dari sebuah program. Pada perhitungan whitebox menguji dengan menghitung 3 parameter yaitu cyclomatic complexity, region, dan independent path. Cyclomatic complexity adalah menghitung jumlah path dari edge dan node yang ada pada flowgraph. Kemudian menghitung region berdasarkan predicate node yaitu jumlah if else pada flowgraph. Langkah terakhir adalah menyusun path pada flowgraph berdasarkan jumlah path yang dihitung pada cyclomatic complexity.

1. Flowchart dan Flowgraph Menu Home

Pada gambar 6 adalah flowchart (logika program) dan flowgraph (aliran program) pada menu home. Setelah menganalisis flowchart dan flowgraph adalah menghitung cyclomatic complexity, region, dan independent path.

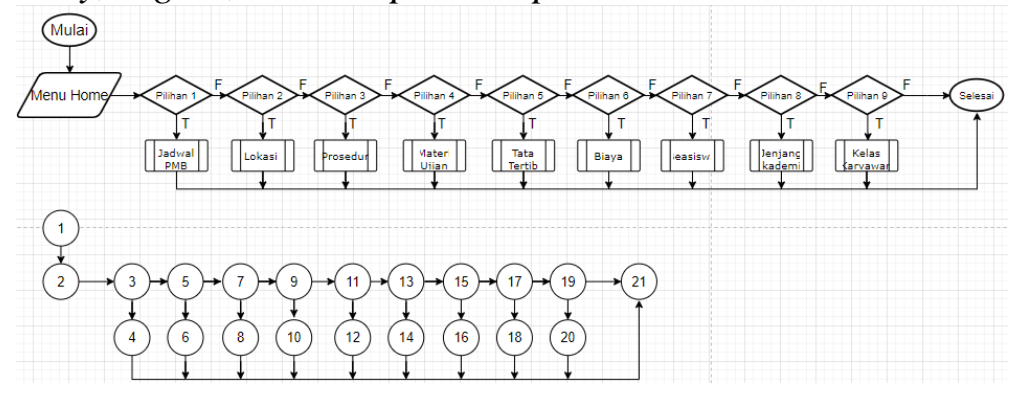

Gambar 6. Flowchart dan flowgraph Menu Home

Tabel 9. Perhitungan Cyclomatic complexity, Region, dan Path pada Flowgraph Menu Home

\begin{tabular}{lc}
$\begin{array}{c}\text { Menghitung Cyclomatic Complexity dari } \\
\text { Edge dan Node }\end{array}$ & $\begin{array}{c}\text { Menghitung Region berdasarkan Predicate } \\
\text { Node }(\mathbf{P}), \text { dimana } \mathbf{P}=9 .\end{array}$ \\
\hline $\mathrm{E}=29$ & $\mathrm{~V}(\mathrm{G})=\mathrm{P}+1$ \\
$\mathrm{~N}=21$ & $=9+1$ \\
$\mathrm{~V}(\mathrm{G})=\mathrm{E}-\mathrm{N}+2$ & $=10$ \\
$=29-21+2=10$ & Jadi Region $($ R $)$ pada flowgraph $=10$ \\
Jadi, jumlah Path $=10$ Path & \\
\hline
\end{tabular}




\section{Path pada flowgraph di atas}

Path $1=1-2-3-4-21$

Path $2=1-2-3-5-6-21$

Path $3=1-2-3-5-7-8-21$

Path $4=1-2-3-5-7-9-10-21$

Path $5=1-2-3-5-7-9-11-12-21$
Path $6=1-2-3-5-7-9-11-13-14-21$

Path $7=1-2-3-5-7-9-11-13-15-16-21$

Path $8=1-2-3-5-7-9-11-13-15-17-18-21$

Path $9=1-2-3-5-7-9-11-13-15-17-19-20-21$

Path $10=1-2-3-5-7-9-11-13-15-17-19-21$

2. Flowchart dan Flowgraph Menu Call us

Pada gambar 7 adalah flowchart (logika program) dan flowgraph (aliran program) pada menu call us. Setelah itu menghitung cyclomatic complexity, predicate node (region), dan independent path.

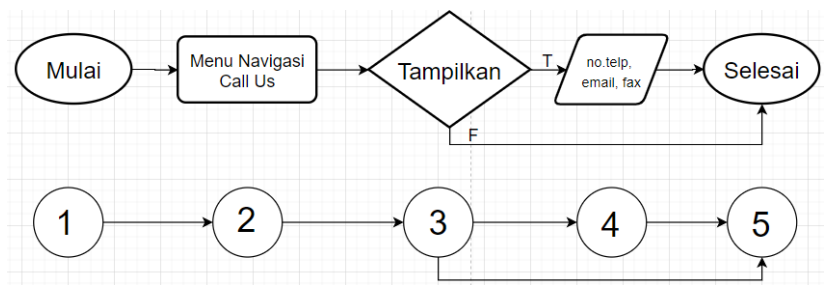

Gambar 7. Flowchart dan flowgraph Menu Call us

Tabel 10. Perhitungan Cyclomatic complexity, Region, dan Path pada Flowgraph Menu Call us

\begin{tabular}{|c|c|c|}
\hline $\begin{array}{c}\text { Menghitung Cyclomatic } \\
\text { Complexity dari Edge dan } \\
\text { Node }\end{array}$ & $\begin{array}{c}\text { Menghitung Region } \\
\text { berdasarkan Predicate Node } \\
\text { (P), dimana } \mathbf{P}=1 \text {. }\end{array}$ & $\begin{array}{c}\text { Path pada flowgraph } \\
\text { di atas }\end{array}$ \\
\hline $\begin{array}{l}\mathrm{E}=5 \\
\mathrm{~N}=5 \\
\begin{aligned} \mathrm{V}(\mathrm{G}) & =\mathrm{E}-\mathrm{N}+2 \\
& =5-5+2 \\
& =2\end{aligned} \\
\text { Jadi, jumlah Path = 2 Path }\end{array}$ & $\begin{array}{l}\mathrm{V}(\mathrm{G})=\mathrm{P}+1 \\
\quad=1+1 \\
\quad=2 \\
\text { Jadi } \\
\text { Region }(R) \text { pada flowgraph }=2\end{array}$ & $\begin{array}{l}\text { Path } 1=1-2-3-4-5 \\
\text { Path } 2=1-2-3-5\end{array}$ \\
\hline
\end{tabular}

3. Flowchart dan Flowgraph Menu Daftar

Pada gambar 8 adalah flowchart (logika program) dan flowgraph (aliran program) pada menu daftar. Setelah menganalisis flowchart dan flowgraph adalah menghitung cyclomatic complexity, predicate node (region), dan independent path.

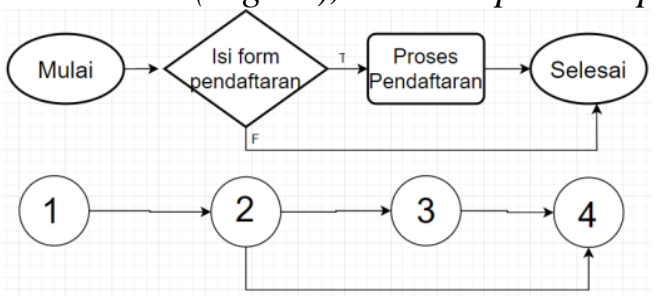

Gambar 8. Flowchart dan flowgraph Menu Daftar

Tabel 11. Perhitungan Cyclomatic complexity, Region, dan Path pada Flowgraph Menu Daftar

\begin{tabular}{lcl}
\hline $\begin{array}{c}\text { Menghitung Cyclomatic } \\
\text { Complexity dari Edge dan } \\
\text { Node }\end{array}$ & $\begin{array}{c}\text { Menghitung berdasarkan } \\
\text { Predicate Node }(\mathbf{P}), \text { dimana } \\
\mathbf{P}=\mathbf{1 .}\end{array}$ & $\begin{array}{c}\text { Path pada flowgraph di } \\
\text { atas }\end{array}$ \\
\hline $\mathrm{E}=4$ & $\mathrm{~V}(\mathrm{G})=\mathrm{P}+1$ & Path $1=1-2-3-4$ \\
$\mathrm{~N}=4$ & $=1+1$ & Path $2=1-2-4$ \\
$\mathrm{~V}(\mathrm{G})=\mathrm{E}-\mathrm{N}+2$ & $=2$ & \\
\hline
\end{tabular}




$\begin{array}{ll}=4-4+2 & \text { Jadi Region } \\ =2 & \text { flowgraph }=2\end{array}$

Jadi, jumlah Path $=2$ Path

4. Flowchart dan Flowgraph Menu Login

Pada gambar 9 adalah flowchart (logika program) dan flowgraph (aliran program) pada menu login. Setelah menganalisis flowchart dan flowgraph adalah menghitung cyclomatic complexity, predicate node (region), dan independent path.

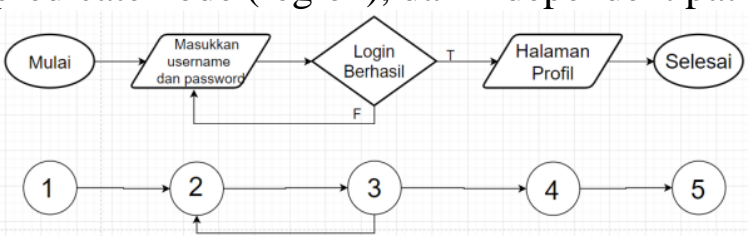

Gambar 9. Flowchart dan flowgraph Menu Login

Tabel 12. Perhitungan Cyclomatic complexity, Region, dan Path pada Flowgraph Menu Login

$\begin{array}{ccc}\text { Menghitung Cyclomatic } & \text { Menghitung berdasarkan } & \text { Path pada flowgraph di } \\ \text { Complexity dari Edge dan } & \text { Predicate Node }(\mathrm{P}), \text { dimana } & \text { atas }\end{array}$

\begin{tabular}{|c|c|c|c|}
\hline Node & $\mathbf{P}=1$ & & \\
\hline $\mathrm{E}=5$ & $V(G)=P+1$ & & Path $1=1-2-3-2-3-4-5$ \\
\hline $\mathrm{N}=5$ & $=1+1$ & & Path $2=1-2-3-4-5$ \\
\hline$V(G)=E-N+2$ & $=2$ & & \\
\hline$=5-5+2$ & Jadi Region $(R)$ & pada & \\
\hline$=2$ & flowgraph $=2$ & & \\
\hline Jadi, jumlah Path $=2$ Path & & & \\
\hline
\end{tabular}

Tabel 13. Hasil pengujian aplikasi dengan metode whitebox

\begin{tabular}{cccc}
\hline Flowgraph & Cyclomatic Complex city (cc) & Region $(\mathbf{R})$ & Independen Path \\
\hline Menu Home & 10 & 10 & 10 \\
Menu Call us & 2 & 2 & 2 \\
Menu Daftar & 2 & 2 & 2 \\
Menu Login & 2 & 2 & 2 \\
Jumlah & 16 & 16 & 16 \\
\hline
\end{tabular}

Pada tabel 13 adalah hasil pengujian aplikasi dengan metode whitebox secara keseluruhan. Dengan mendapatkan jumlah cyclomatic complexity, region, dan independent path yang sama yaitu 16, artinya logika dan alur program yang dibuat sudah sesuai yang diharapkan dan tidak perlu melakukan compile ulang.

\section{Hasil Pengujian Metode Blackbox pada Aplikasi}

Metode blackbox adalah pengujian terhadap fungsi operasi dan kegunaan aplikasi apakah pengujian berhasil dan hasil yang didapat sudah sesuai yang diharapkan atau belum. Pada tabel 14 adalah hasil pengujian aplikasi dengan metode blackbox.

Tabel 14. Hasil pengujian aplikasi dengan metode blackbox

\begin{tabular}{cccc}
\hline Pengujian & Bentuk Pengujian & Hasil yang diharapkan & Hasil pengujian \\
\hline Menu Home & Masuk ke halaman utama & Menampilkan menu & Berhasil \\
& & jadwal, lokasi, prosedur, \\
& materi ujian, tata tertib, & \\
& biaya, beasiswa, jenjang \\
& akademik, kelas \\
& karyawan, serta navigasi \\
\hline
\end{tabular}




\begin{tabular}{|c|c|c|c|}
\hline & & call us dan PMB & \\
\hline Menu Call Us & Menekan navigasi call us & $\begin{array}{c}\text { Menampilkan informasi } \\
\text { kontak PMB }\end{array}$ & Berhasil \\
\hline Menu Daftar & $\begin{array}{l}\text { Menekan tombol pendaftaran } \\
\text { pada navigasi PMB dan } \\
\text { menginput data form }\end{array}$ & $\begin{array}{l}\text { Menampilkan formulir } \\
\text { pendaftaran dan data } \\
\text { berhasil diinput serta } \\
\text { tersimpan dalam } \\
\text { database }\end{array}$ & Berhasil \\
\hline Menu Sign In & $\begin{array}{l}\text { Login dengan username } \\
\text { password yang telah } \\
\text { didaftarkan }\end{array}$ & $\begin{array}{c}\text { Menampilkan halaman } \\
\text { sign in dan berhasil } \\
\text { masuk ke menu data } \\
\text { profil }\end{array}$ & Berhasil \\
\hline
\end{tabular}

\section{Pembahasan}

Aplikasi sistem informasi smart register online berbasis Android dikembangkan menggunakan metode waterfall memiliki halaman menu utama Home. Pada halaman menu utama memiliki 3 tombol bottom navigasi menu yaitu home, call us, dan pmb. Pada menu utama atau Home terdiri dari 9 main menu yang terdiri dari jadwal (berisi jadwal pendaftaran), lokasi ujian, prosedur pmb, materi ujian, tata tertib, biaya kuliah, beasiswa, jenjang akademik, dan kelas karyawan. Selanjutnya pada bottom navigasi menu call us berisi nomor telepon, fax, dan email customer service pmb. Bila calon mahasiswa baru masih belum jelas mengenai informasi yang disampaikan pada aplikasi atau ada masalah ketika pendaftaran online camaba dapat menghubungi kontak yang ada. Kemudian navigasi menu PMB berisi 2 menu yaitu daftar dan sign in. Pada menu daftar adalah proses registrasi pendaftaran camaba dengan mengisikan formulir. Setelah melakukan proses pendaftaran camaba dapat melakukan sign in atau login untuk melihat hasil registrasi pendaftaran yang telah berhasil. Selanjutnya adalah pembahasan tentang implementasi algoritma brute force. Pada pengimplementasian algortima brute force pada proses pengisian form program studi dengan pencarian kata "Teknik Informatika S1" menggunakan string "Informatika" didapatkan dengan melakukan 8 langkah pencarian. Pencarian kata menggunakan brute force dimulai dari kiri dan bergeser terus ke kanan hingga string yang diinputkan cocok dengan kata yang dicari. Dengan penggunaan algoritma brute force akan lebih memudahkan dalam pencarian daftar prodi tanpa harus mengetik seluruh kata. Kemudian dilakukan pengujian aplikasi menggunakan metode whitebox dan blackbox.

Hasil Pengujian menggunakan metode whitebox dilakukan pembuatan flowchat, flowgraph, serta 4 pengujian terhadap menu utama Home, menu call us, menu daftar, dan menu sign in dengan menghitung 3 parameter yaitu cyclomatic complexity, region, dan independent path. Adapun pengujian pada menu utama Home didapatkan hasil pada cyclomatic complexity yaitu 10 path, 10 region, dan 10 independent path. Kemudian pengujian pada menu call us, menu daftar, dan menu sign in didapatkan hasil yang sama yakni dengan hasil cyclomatic complexity yaitu 2 path, 2 region, dan 2 independent path. Maka diperoleh hasil yang berjumlah sama yaitu 16 pada ketiga parameter yang diuji.

Pengujian aplikasi menggunakan metode blackbox dilakukan bentuk pengujian terhadap hasil yang diharapkan, dan dari pengujian yang telah dilakukan dinyatakan berhasil. Pengujian dilakukan pada menu utama home, menu call us, menu daftar, dan menu sign in. 


\section{SIMPULAN}

Pengembangan Aplikasi sistem informasi smart register online berbasis Android menggunakan metode waterfall dalam pengembangan aplikasi yaitu dengan tahapan analisis sistem, desain sistem, coding, testing program, dan pemeliharaan. Kemudian dengan implementasi algortima brute force membantu dalam pencarian string program studi yaitu kata "Teknik Informatika S1" dengan string "Informatika" diperoleh dengan 8 langkah pencarian. Hasil pengujian whitebox dengan menghitung parameter cyclomatic complexity, region, dan independent path dari 4 pengujian whitebox diperoleh hasil sama yaitu berjumlah 16. Pada hasil pengujian aplikasi dengan metode blackbox dinyatakan berhasil dan hasil pengujian sesuai yang diharapkan.

\section{REFERENSI}

Amin, M. M., Maseleno, A., Shankar, K., Perumal, E., Vidhyavathi, R. M., \& Lakshmanaprabu, S. K. (2018). Active Database System Approach and Rule Based in the Development of Academic Information System. International Journal of Engineering \& Technology, 7(2.26), 95-101.

Choi, Y., \& Park, D. H. (2017). Development of Youke mining system with Youke's travel demand and insight based on web search traffic information. Journal of Intelligence and Information Systems, 23(3), 155-175.

Irawan, A., Hasna, A., \& Pahlevi, R. (2016). Sistem Informasi Perdagangan Pada PT Yoltan Sari Menggunakan PHP Berbasis Web. Jurnal Positif. 1(2), 8-15.

Khoiriyah, S., \& Manikam, R. M. (2019). Analisa dan Perancangan Sistem Perhitungan Insentif Marketing Trade Menggunakan Sistem Remunerasi. EDUMATIC: Jurnal Pendidikan Informatika, 3(2), 99-108.

Kim, S. J., Bae, Y. M., \& Choi, Y. J. (2018). Design and Implementation of Real-time Augmented Reality Building Information System Combined with 3D Map. Journal of The Korea Computer Graphics Society, 24(4), 39-54.

Klausen, P. (2017). Java 1: Basic syntax and semantics: Software Development. Diambil dari https://bit.ly/2AvJgMV.

Kouziokas, G. N. (2016). Geospatial based information system development in public administration for sustainable development and planning in urban environment. European Journal of Sustainable Development, 5(4), 347-347.

Pramana, A., Watrianthos, R., \& Purnama, I. (2019). Sistem Informasi Pendaftaran Mahasiswa Baru Berbasis Android. Jurnal Informatika Upgris, 5(2), 121-125.

Pressman, R.S. (2015). Rekayasa Perangkat Lunak: Pendekatan Praktisi Buku I. Yogyakarta: Andi.

Sitanggang, A. L., Loi, M. H, \& Indra, E. (2019). Rancang Bangun Aplikasi Sistem Ujian Masuk SMA Berbasis Android (Studi Kasus SMA Amir Hamzah Medan). Jurnal Sistem Informasi Ilmu Komputer Prima (JUSIKOM PRIMA), 2(2), 8-16.

Sumi, A. S., Purnawansyah, P., \& Syafie, L. (2018). Analisa Penerapan Algoritma Brute Force Dalam Pencocokan String. SAKTI (Seminar Ilmu Komputer Dan Teknologi Informasi), 3(2), 88-92.

Utomo, R. P., Budiman, A., \& Triono, J. (2017). Aplikasi Ujian Online Masuk Universitas Merdeka Madiun Berbasis Android. Jurnal Pilar Teknologi, 2(1), 29-39.

Yulistina, D., \& Arianti, B. D. D. (2019). E-Katalog Sebagai Sistem Informasi Pemasaran Kopi Sapit Berbasis Web. EDUMATIC: Jurnal Pendidikan Informatika, 3(2), 45-52.

Yuni, P. (2019). Aplikasi Berbasis Android Penerimaan Mahasiswa Baru pada Universitas PGRI Madiun. SENATIC (Seminar Nasional Teknologi Informasi Dan Komunikasi), 2(1), 125-127. 